\title{
PENGARUH DEVIDEND PER SHARE (DPS), EARNING PER SHARE (EPS) DAN NET PROFIT MARGIN (NPM) TERHADAP HARGA SAHAM PADA PERUSAHAAN PERSERO YANG TERDAFTAR DI BURSA EFEK INDONESIA (BEI) PERIODE 2013-2017
}

\author{
Novalia Selvi Br Parhusip ${ }^{1 *}$, Raswan Udjang². \\ Universitas Mercu Buana Yogyakarta \\ Smnovalia@gmail.com
}

\begin{abstract}
This study aims to analyse the effects of Dividend Per Share, Earning Per Share and Net Profit Margin simultaneously and partially on stock price. This study was taken because there are still differences between the research study with each other. The method of purposive sampling was used in this sample of research. The sample of the research from twenty companies, only eleven are selected because the financial statement from each company are complete since 2013-2017. The analysis method used is multiple linear regression analysis. By using regression analysis, this study provides evidence that Devidend per Share have significant positive effect on stock prices. Earning per Share have significant positive effect on stock prices. Net Profit Margin have significant negative effect on stock prices.
\end{abstract}

Keywords: Dividend Per Share, Earning Per Share and Stock Price.

\section{ABSTRAK}

Penelitian ini bertujuan untuk menganalisis pengaruh Dividen Per Saham, Earning Per Share dan Net Profit Margin secara simultan dan parsial terhadap harga saham. Penelitian ini diambil karena masih ada perbedaan antara penelitian dengan penelitian yang lain. Metode purposive sampling digunakan dalam sampel penelitian ini. Sampel penelitian dari dua puluh perusahaan, hanya sebelas dipilih karena laporan keuangan dari masing-masing perusahaan selesai sejak 2013-2017. Metode analisis yang digunakan adalah analisis regresi linier berganda. Dengan menggunakan analisis regresi, penelitian ini memberikan bukti bahwa Deviden per Saham memiliki efek positif yang signifikan terhadap harga saham. Laba per Saham memiliki efek positif yang signifikan terhadap harga saham. Net Profit Margin berpengaruh negatif signifikan terhadap harga saham.

Kata Kunci : Dividend Per Share, Earning Per Share dan Harga Saham.

\section{PENDAHULUAN}

Di era globalisasi ini, semakin banyak perusahaan yang tumbuh dan berkembang menjadi perusahaan besar. Semakin besar perusahaan, semakin besar pula dana yang dibutuhkan untuk menjalankan semua aktivitas perusahaan tersebut. Perusahaan bisa memperoleh dana melalui bebesrapa cara yaitu melalui pinjaman lembaga keuangan dan pasar modal (Restu, 2012:1).

Pasar modal (capital market) merupakan pasar untuk berbagai instrumen keuangan jangka panjang yang bisa diperjualbelikan, baik surat utang (obligasi), ekuiti (saham), reksa dana, instrumen derivatif maupun instrumen lainnya. Pasar modal merupakan sarana pendanaan bagi perusahaan maupun institusi lain (misalnya pemerintah), dan sebagai sarana bagi kegiatan berinvestasi. Dengan demikian, pasar modal memfasilitasi berbagai sarana dan prasarana kegiatan jual beli dan kegiatan terkait lainnya.

Manfaat pasar modal bagi investor adalah tempat menanamkan modal untuk mendapatkan keuntungan, pengelolaan yang profesional dan transparan bisa meminimalisir risiko investasi, mencari keuntungan dan deviden dapat mengambil alih kepemilikan suatu perusahaan, memperluas jaringan bisnis, sebagai tempat Jual-beli instrumen modal dan memiliki hak suara pada Rapat Umum Pemegang Saham (RUPS). Manfaat pasar modal bagi 
masyarakat adalah menambah lapangan perkerjaan, merasakan manfaat dari produk suatu perusahaan, mempermudah dalam mencari barang, konsumsi dan membuka kesempatan bagi masyarakat untuk berinvestasi. Manfaat pasar modal bagi emiten adalah sarana dalam mencari dana segar, mengurangi ketergantungan pada bank, mempermudah perusahaan untuk ekspansi usaha dan meningkatkan produktivitas.

Saham adalah surat berharga yang menunjukkan bagian kepemilikan atas suatu perusahaan. Membeli saham berarti investor telah memiliki hak kepemilikan atas perusahaan tersebut. Maka dari itu, investor berhak atas keuntungan perusahaan dalam bentuk dividen, pada akhir tahun periode pembukuan perusahaan. Saham (stock) merupakan salah satu instrumen pasar keuangan yang paling popular. Menerbitkan saham merupakan salah satu pilihan perusahaan ketika memutuskan untuk pendanaan perusahaan. Pada sisi yang lain, saham merupakan instrument investasi yang banyak dipilih para investor karena saham mampu memberikan tingkat keuntungan yang menarik. Saham dapat didefinisikan sebagai tanda penyertaan modal seseorang atau pihak (badan usaha) dalam suatu perusahaan atau perseroan terbatas. Dengan menyertakan modal tersebut, maka pihak tersebut memiliki klaim atas pendapatan perusahaan, klaim atas aset perusahaan, dan berhak hadir dalam Rapat Umum Pemegang Saham (RUPS).

Devidend Per Share merupakan total deviden yang akan dibagikan pada investor untuk setiap lembar saham. Devidend Per Share yang tinggi mencerminkan perusahaan memiliki prospek yang baik karena dapat membayarkan Devidend Per Share dalam jumlah yang tinggi. Hal ini akan menarik investor untuk membeli saham perusahaan tersebut. Dengan banyaknya saham yang dibeli mengakibatkan harga saham perusahaan tersebut naik (Intan, 2009: 21).
Earning Per Share merupakan rasio yang menunjukkan berapa besar keuntungan (return) yang diperoleh investor atau pemegang saham per lembar saham. Semakin tinggi nilai Earning Per Share tentu saja menggembirakan pemegang saham karena semakin besar laba yang disediakan untuk pemegang saham. Earning per share merupakan informasi yang dianggap paling mendasar dan berguna, karena bisa menggambarkan prospek earnings perusahaan di masa depan.

Net Profit Margin merupakan rasio yang menunjukkan seberapa besar persentase laba bersih yang diperoleh dari setiap penjualan (Rescyana, 2012:105). Rasio ini menginterpretasikan tingkat efisiensi perusahaan, yakni sejauh mana kemampuan perusahaan menekan biayabiaya operasionalnya pada periode tertentu. Semakin besar rasio ini semakin baik karena kemampuan perusahaan dalam mendapatkan laba melalui penjualan cukup tinggi serta kemampuan perusahaan dalam menekan biaya-biayanya cukup baik. Sebaliknya,jika rasio ini semakin turun maka kemampuan perusahaan dalam mendapatkan laba melalui penjualan dianggap cukup rendah. Selain itu, kemampuan perusahaan dalam menekan biaya-biayanya dianggap kurang baik sehingga investorpun enggan untuk menanamkan dananya. Hal tersebut mengakibatkan harga saham perusahaan ikut mengalami penurunan.

Berdasarkan latar belakang yang telah dipaparkan, dapat dikatakan bahwa dari masa ke masa persaingan bisnis semakin kompetitif dan variatif karena banyaknya perusahaan-perusahaan besar. Seiring dengan pesatnnya perkembangan tersebut, kebutuhan informasi yang relevan terhadap pengambilan keputusan investasi di dalam pasar modal juga semakin meningkat. Untuk membantu memberikan referensi kepada investor terkait faktor yang mempengaruhi harga saham, peneliti 
tertarik untuk melakukan penelitian karena sebelumnya belum ada yang meneliti terkait pengaruh variabel Devidend per share, earning per share, dan Net profit margin terhadap harga saham Pada Perusahaan Persero Yang Terdaftar Di Bursa Efek Indonesia (BEI) Periode 2013-2017.

\section{TINJAUAN PUSTAKA \\ Pengertian Saham}

Saham dapat didefinisikan sebagai tanda penyertaan atau kepemilikan seseorang atau badan usaha dalam suatu perusahaan atau perseroan terbatas (Darmadji, 2012: 05). Saham merupakan secarik kertas yang menunjukkan hak pemodal (pihak yang memiliki kertas tersebut) untuk memperoleh bagian dari prospek atau kekayaan organisasi yang menerbitkan sekuritas tersebut dan berbagai kondisi yang memungkinkan pemodal tersebut menjalankan haknya (Husnan, 2013 : 29). Saham merupakan salah satu instrument pasar modal yang paling banyak diminati oleh investor, karena mampu memberikan tingkat pengembalian yang menarik. Saham adalah kertas yang tercantum dengan jelas nilai nominal, nama perusahaan, dan diikuti dengan hak dan kewajiban yang telah dijelaskan kepada setiap pemegangnya (Fahmi, 2012:81). Menerbitkan saham merupakan salah satu pilihan perusahaan ketika memutuskan untuk pendanaan perusahaan. Pada sisi yang lain, saham merupakan instrument investasi yang banyak dipilih para investor karena saham mampu memberikan tingkat keuntungan yang menarik.

\section{Jenis-jenis Saham}

Saham merupakan surat berharga yang paling populer dan dikenal luas dimasyarakat. Menurut Darmadji (2012:6), ada beberapa jenis saham yaitu:

Ditinjau dari segi kemampuan dalam hak tagih atau klaim, maka saham terbagi atas:
a. Saham biasa (common stock).
b. Saham preferen (preferred stock).
Dilihat dari cara pemeliharaannya, saham dibedakan menjadi:

a. Saham atas unjuk (bearer stock)

b. Saham atas nama (registered stock),

Ditinjau dari kinerja perdagangannya, maka saham dapt dikategorikan menjadi:

a. Saham unggulan (blue-chip stock),

b. Saham pendapatan (income stock), c. Saham pertumbuhan (growth stock-well known),

d. Saham spekulatif (spekulative stock),

e. Saham sklikal (counter cyclical stock).

Faktor yang Mempengaruhi Harga Saham

Terdapat beberapa faktor yang dapat mempengaruhi fluktuasi harga sahamdi pasar modal, hal ini terjadi karena harga saham dapat mempengaruhi oleh faktor eksternal dari perusahaan maupun faktor internal perusahaan. Harga saham dipengaruhi oleh beberapa faktor utama (Brigham dan Houston, 2010:33), yaitu:

\section{Faktor internal}

Pengumuman tentang pemasaran produksi penjualan seperti pengiklanan, rincian kontrak, perubahan harga, penarikan produk baru, laporan produksi, laporan keamanan dan laporan penjualan.

a) Pengumuman pendanaan, seperti pengumuman yang berhubungan dengan ekuitas dan hutang.

b) Pengumuman badan direksi manajemen (management board ofdirector ann nouncements) seperti perubahan dan pergantian direktur, manajemen dan struktur organisasi.

c) Pengumuman pengambilalihan diverifikasi seperti laporan mergerinvestasi, investasi ekuitas, laporan take over oleh pengakuisisian dan diakuisisi, laporan investasi dan lainnya.

d) Pengumuman investasi seperti melakukan ekspansi pabrik pengembangan riset dan penutupan usah lainnya.

e) Pengumuman ketenagakerjaan (labour announcements), seperti negosiasi baru, kotrak baru, pemogokan dan lainnya.

f) Pengumuman laporan keuangan perusahaan, seperti:

\section{Devidend Per Share}

Dividend per Share merupakan total semua dividen tunai yang dibagikan kepada pemegang saham dibandingkan dengan jumlah saham yang beredar (Hutami, 2012).

\section{Earning Per Share}

Earning Per Share adalah bentuk pemberian keuntungan yang diberikan kepada para pemegang saham dari setiap lembar saham yang dimiliki (Fahmi, 2012 : 288). 
Net Profit Margin

Net profit margin merupakan hubungan antara laba bersih setelah pajak dengan penjualan menunjukkan kemampuan manajemen dalam menjalankan perusahaan sampai cukup berhasil dalam memulihkan/mengendalikan harga pokok barang dagangan/jasa, beban operasi, penyusutan, bunga pinjaman dan pajak (Kasmir, 2012: 197).

\section{Faktor eksternal}

a. Pengumuman dari pemerintah seperti perubahan suku bunga tabungan dan deposito kurs valuta asing, inflasi, serta berbagai regulasi dan regulasi ekonomi yang dikeluarkan oleh pemerintah.

b. Pengumuman hukum seperti tuntutan terhadap perusahaan atau terhadap manajernya dan tuntutan perusahaan terhadap manajernya.

c. Pengumuman industri sekuritas, seperti laporan pertemuan tahunan insider trading, volume atau harga saham perdagangan pembatasan atau penundaan trading.

Kerangka pemikiran merupakan sintesis dari tinjauan teori dan tinjauan penelitian sebelumnya serta alasan-alasan logis. Adapun kerangka pemikiran dari penelitian ini adalah:

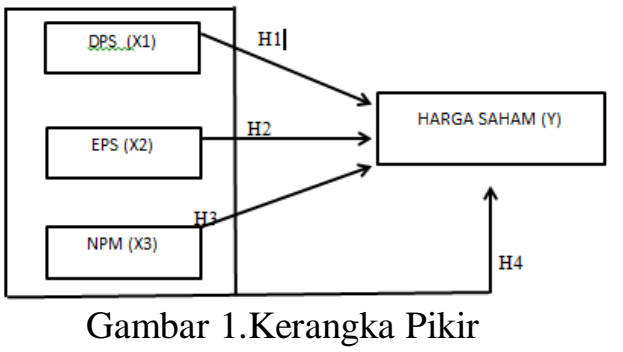

\section{METODE PENELITIAN}

Metode dan Teknik Pengambilan Sampel Penentuan sampel dalam penelitian ini diambil dengan metode purposive sampling. Adapun teknik yang digunakan yaitu purposive sampling yaitu dimana peneliti menentukan pengambilan sampel dengan cara menetapkan ciri-ciri khusus yang sesuai dengan tujuan penelitian sehingga dapat menjawab permasalahan penelitian. Menurut Margono (2004:128), pemilihan sekelompok subjek dalam purposive sampling didasarkan atas ciri-ciri tertentu yang dipandang mempunyai sangkut paut yang erat dengan ciri-ciri populasi yang sudah diketahui sebelumnya, dengan kata lain unit sampel yang dihubungi disesuaikan dengan kriteriakriteria tertentu yang diterapkan berdasarkan tujuan penelitian. Populasi dalam penelitian ini adalah Perusahaan Persero yang Terdaftar di BEI Periode 2013-2017. Penentuan sampel dalam penelitian ini diambil dengan metode purposive sampling. Dimana sampel dipilih berdasarkan kriteria tertentu. Sampel dalam penelitian ini yaitu data laporan keuangan Perusahaan Persero yang Terdaftar di BEI Periode 2013-2017. Adapun kriteria yang digunakan untuk memilih sampel adalah sebagai berikut:

a. Perusahaan persero yang terdaftar di BEI pada tahun 2013-2017

b. Perusahaan persero yang menerbitkan laporan keuangan yang telah di audit oleh auditor independen dalam periode 2013-2017

c. Perusahaan memiliki data yang lengkap mengenai varibel-variabel yang digunakan dalam penelitian.

Berdasarkan kriteria tersebut, Jumlah sampel yang digunakan dalam penelitian ini ada sebanyak 11 Perusahaan Persero yang Terdaftar di BEI pada Periode 2013-2017 yaitu:

\begin{tabular}{|c|c|c|}
\multicolumn{4}{l}{} & Tabel III.1 \\
\hline NO & $\begin{array}{c}\text { KODE } \\
\text { EFEK }\end{array}$ & $\begin{array}{c}\text { NAMA } \\
\text { PERUSAHAAN }\end{array}$ \\
\hline 1 & BBNI & $\begin{array}{c}\text { Bank Negara Indonesia } \\
\text { (Persero) Tbk }\end{array}$ \\
\hline 2 & BBRI & $\begin{array}{c}\text { Bank Rakyat Indonesia } \\
\text { (Persero) Tbk }\end{array}$ \\
\hline 3 & BBTN & $\begin{array}{c}\text { Bank Tabungan Negara } \\
\text { (Persero) Tbk }\end{array}$ \\
\hline 4 & BMRI & $\begin{array}{c}\text { Bank Mandiri (Persero) } \\
\text { Tbk }\end{array}$ \\
\hline 5 & JSMR & $\begin{array}{c}\text { Jasa Marga (Persero) } \\
\text { Tbk }\end{array}$ \\
\hline 6 & KAEF & $\begin{array}{c}\text { Kimia Farma (Persero) } \\
\text { Tbk }\end{array}$ \\
\hline 7 & PTBA & $\begin{array}{c}\text { Tambang Batubara } \\
\text { Bukit Asam } \\
\text { (Perssero) Tbk }\end{array}$ \\
\hline 8 & SMBR & $\begin{array}{c}\text { Semen Baturaja } \\
\text { (Persero) Tbk }\end{array}$ \\
\hline 9 & SMGR & $\begin{array}{c}\text { Semen Indonesia } \\
\text { (Persero) Tbk }\end{array}$ \\
\hline 10 & WIKA & $\begin{array}{c}\text { Wijaya Karya (Persero) } \\
\text { Tbk }\end{array}$ \\
\hline 11 & WSKT & $\begin{array}{l}\text { Waskita Karya } \\
\text { (Persero) Tbk }\end{array}$ \\
\hline
\end{tabular}




\section{Metode Analisis Data}

Dalam penelitian ini, kami menggunakan metode analisis data kualitatif dan kuantitatif. Metode analisis data kualitatif dengan menggunakan rasio. Untuk mengetahui total semua dividen tunai yang dibagikan dibandingkan dengan jumlah saham yang beredar digunakan rumus berikut :

$$
\text { DPS }=\frac{\text { Deviden Tunai }}{\text { Jumlah Saham Beredar }}
$$

Untuk mengetahui berapa keuntungan yang didapat per lembar saham, maka digunakan rumus berikut:

$$
\text { EPS }=\frac{\text { Laba Bersih Setelah Pajak }}{\text { Jumlah Saham Beredar }}
$$

Untuk mengetahui berapa laba bersih dari setiap penjualan, maka digunakan rumus berikut:

$\mathrm{NPM}=\frac{\text { Pendapatan Bersih }}{\text { Penjualan Bersih }}$

Dalam penelitian ini, peneliti menggunakan model analisis sebagai berikut: Metode deskriptif adalah penelitian yang dilakukan untuk mengetahui keberadaan variabel mandiri, baik hanya pada satu variabel atau lebih (variabel yang berdiri sendiri) tanpa membuat perbandingan dan mencari hubungan variabel itu dengan variabel yang lain". Sugiyono (2009:35).

\section{Uji Asumsi Klasik}

Uji asumsi klasik adalah analisis yang dilakukan untuk menilai apakah didalam sebuah model regresi linear berganda yang berbasis ordinary least square (OLS). Jadi analisis regresi yang tidak berdasarkan OLS tidak memerlukan persyaratan asumsi klasik, misalnya regresi logistic atau regresi ordinal. Uji asumsi klasik yang sering digunakan yaitu uji multikolinearitas, uji heteroskedastisitas, uji normalitas, uji autokorelasi dan uji linearitas. Tidak ada ketentuan yang pasti tentang urutan uji mana dulu yang harus dipenuhi.

\section{Analisis Regresi Linier Berganda}

Teknik regresi linier berganda digunakan untuk mengetahui hubungan fungsional antara variabel dependen dihubungkan dengan dua atau lebih variabel independen. Rumus dari regresi linier bergandasebagai berikut:

$$
\begin{aligned}
& \mathrm{Y}=\mathrm{a}+\mathrm{b} 1 \mathrm{X} 1+\mathrm{b} 2 \mathrm{X} 2+\mathrm{b} 3 \mathrm{X} 3+\mathrm{e} \\
& \text { Dimana: } \\
& \mathrm{Y}=\text { Harga saham } \\
& \mathrm{X} 1=\text { Devidend Per Share } \\
& \mathrm{X} 2=\text { Earning Per Share } \\
& \mathrm{X} 3=\text { Net Profit Margin }
\end{aligned}
$$

$$
\begin{aligned}
& \mathrm{a}=\text { Konstanta } \\
& \text { b1 }=\text { Koefisien regresiDevidend Per } \\
& \text { Share } \\
& \text { b2= Koefisien regresiEarning Per Share } \\
& \text { b3= Koefisien regresi Net Profit Margin } \\
& \text { e = Error term }
\end{aligned}
$$

\section{Uji Kelayakkan Model}

\section{Koefisien Determinasi (R2)}

Koefisien menunjukan seberapa besar pengaruh DPS, EPS dan NPM terhadap harga saham. Hal ini ditunjukkan oleh besarnya koefisien determinasi Adjusted $\mathrm{R}$ Square (R2). Keputusannya adalah sebagai berikut: Jika nilai R2 mendekati 0, maka kemampuan DPS, EPS dan NPM dalam mempengaruhi harga saham amat terbatas.Jika nilai R2 mendekati 1, maka kemampuan DPS, EPS dan NPM dalam menjelaskan harga saham memberikan hampir semua informasi yang dibutuhkan untuk memprediksi variasi harga saham.

Uji signifikansi simultan (Uji f statistik)

Uji statistik f merupakan uji signifikansi parameter individual. Nilai statistik $t$ menunjukan seberapa jauh pengaruh DPS, EPS dan NPM secara individual terhadap harga saham. Hasil uji statistik $f$ dapat dilihat pada tabel coefficient. Langkah pengujian :

Merumuskan hipotesis

H0 : $\beta=0$, artinya DPS, EPS dan NPM bukan merupakan penjelas harga saham.

$\mathrm{Ha}: \beta \neq 0$, artinya DPS, EPS dan NPM merupakan penjelas harga saham.

Merumuskan kesimpulan

Uji t (Uji Parsial)

Uji statistik t pada dasarnya menunjukkan apakah semua variabel bebas yang dimasukkan dalam model mempunyai pengaruh secara parsial terhadap variabel terikat. Rumusan hipotesis dalam pengujian secara simultan (uji T)

ditolak.

\section{HASIL PENELITIAN \\ PEMBAHASAN}

DAN

a. Statistik Deskriptif

Hasil penelitian statistic deskriptif dengan menggunakan alat statistik SPSS 16.0 terhadap variabel-variabel yang digunakan dalam penelitian ini dapat dilihat pada tabel berikut: 
Tabel VI.1

Hasil Uji Descriptive Statistik

Descriptive Statistics

\begin{tabular}{|l|r|r|r|r|r|}
\hline & $\mathrm{N}$ & Minimum & Maximum & Mean & Std. Deviation \\
\hline Dps & 55 & 7,79 & 43,23 & 19,9956 & 6,25731 \\
Eps & 55 &, 87 & 95,68 & 19,8287 & 13,49812 \\
Npm & 55 & 8,75 & 28,16 & 19,9918 & 4,53754 \\
harga saham & 55 & 3,15 & 50,05 & 19,9947 & 10,11741 \\
Valid N & 55 & & & \\
(listwise) & & & \\
\hline
\end{tabular}

Sumber: Hasil Output SPSS 16.0

Berdasarkan tabel diatas dapat dilihat bahwa tingkat Harga Saham adalah keuntungan yang diperoleh pemegang saham sebagai hasil dari investasinya besarnya nilai harga saham rata-rata sebesar 19.9947, dengan nilai tertinggi sebesar 50.05 dan nilai minimum sebesar 3.15.

Devidend per Share (DPS) mengukur seberapa tinggi harga saham dibeli oleh para investor dibandingkan dengan laba per saham. Terlihat pada table VI.1 bahwa ratarata DPS harga saham sebesar 19.9956 dengan nilai maksimum 43.23 dan minimum sebesar 7.79.

Earning per Share (EPS) mengukur kemampuan per lembar saham dalam menghasilkan laba. Terlihat pada table VI.1 bahwa rata-rata EPS harga saham sebesar

Table VI.3

Hasil Uji Normalitas

\section{One-Sample Kolmogorov-Smirnov Test}

\begin{tabular}{|ll|l|}
\hline & & Unstandardized Residual \\
\hline $\mathrm{N}$ & & 55 \\
Normal Parameters & Mean &, 0000000 \\
& Std. Deviation & 9,49153606 \\
Most Extreme Differences & Absolute &, 091 \\
& Positive &, 091 \\
& Negative &,- 051 \\
Test Statistic & &, 091 \\
Asymp. Sig. (2-tailed) & &, $200^{\mathrm{c}, \mathrm{d}}$ \\
\hline
\end{tabular}

a. Test distribution is Normal.

b. Calculated from data.

c. Lilliefors Significance Correction.

d. This is a lower bound of the true significance.

Sumber: Hasil Output SPSS 16.0

Dari uji normalitas pada table VI.3 diatas yang telah dilakukan pada data diperoleh Asymp.Sig (2-tailed) pada variabel Devidend per Share (DPS), Earning Per Share (EPS) dan Net Profit Margin (NPM) sebesar 0,200. Nilai tersebut lebih besar dari 0.05 yang dapat disimpulkan bahwa data berdistribusi 19.8287 dengan nilai maksimum 95.68 dan nilai minimum 0.87 .

Net Profit Margin (NPM) mengukur seberapa besar laba bersih yang diperoleh dari setiap penjualan harga saham. Terlihat pada table VI.1 bahwa rata-rata NPM harga saham sebesar 19.9918 dengan nilai maksimum 28.16 dan minimum sebesar 8.75.

\section{Uji Asumsi Klasik}

Uji Normalitas

Uji normalitas diuji dengan menggunakan uji Kolmogorov-Smirnov. Data ini lolos uji masalah apabila nilai Asymp.Sig (2-tailed) lebih besar dari 0.05. Sebaliknya jika nilai Asymp.Sig (2-tailed) lebih kecil dari 0.05 maka data tersebut mengalami normalitas. 
Gambar VI.2

\section{Hasil Uji Heteroskedastisitas}

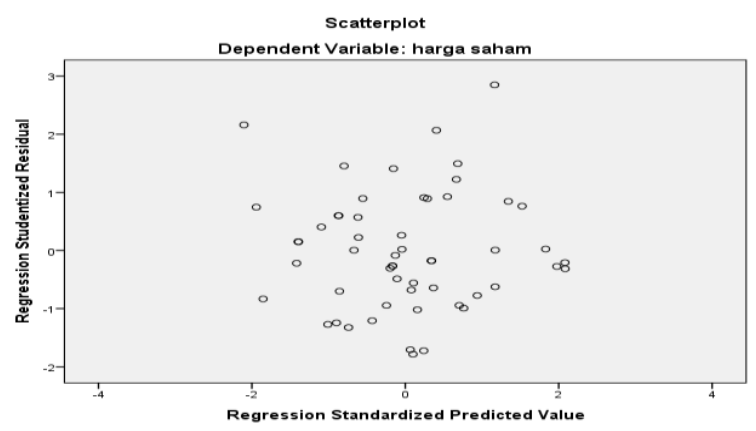

Sumber: Hasil Output SPSS 16.0

Berdasarkan analisis scatterplot diatas dapat dilihat bahwa pada model penelitian ini tidak terjadi masalah heteroskedastisitas. Hal ini dikarenakan, titik scatterplot tidak membentuk pola tertentu melainkan menyebar diatas dan di bawah angka 0 pada sumbuh Y. oleh karena itu model ini dapat diterima.

Uji Multikolinearitas

Berdasarkan Tabel VI.4 variabel yang diteliti memiliki nilai DW sebesar 1,574. Dengan jumlah data $(n)=55$ dan jumlah variabel bebas $(\mathrm{k})=4$ serta $\alpha=5 \%$ diperoleh angka dU $=1,681$ dan $\mathrm{dL}=1,452$. Karena DW sebesar 1,574 terletak diantara dU dan dL (4-dU), dapat disimpulkan tidak terdapat autokorelasi

Table VI.4

Hasil Uji Multikolinearitas

Coefficients $^{\mathrm{a}}$

\begin{tabular}{|c|c|c|c|c|c|c|c|c|}
\hline \multirow[b]{2}{*}{ Model } & \multicolumn{2}{|c|}{$\begin{array}{l}\text { Unstandardized } \\
\text { Coefficients }\end{array}$} & \multicolumn{2}{|c|}{$\begin{array}{l}\text { Standardized } \\
\text { Coefficients } \\
\end{array}$} & \multirow[b]{2}{*}{$\mathrm{T}$} & \multirow[b]{2}{*}{ Sig. } & \multicolumn{2}{|c|}{$\begin{array}{l}\text { Collinearity } \\
\text { Statistics }\end{array}$} \\
\hline & $\mathrm{B}$ & Std. Error & Beta & & & & Tolerance & VIF \\
\hline 1 (Constant) & 26,048 & 6,153 & & & 4,23 & 3,000 & & \\
\hline Dps &, 526 & ,252 & & ,325 & 2,08 &, 042 & ,708 & 1,41 \\
\hline Eps & ,042 & , 106 & & ,056 & ,39 &, 693 & ,863 & 1,15 \\
\hline $\mathrm{Npm}$ &,- 871 & ,359, & &,- 391 & 2,42 & 019 & 665 & 1,50 \\
\hline
\end{tabular}

a. Dependent Variable: harga saham

Sumber: Hasil Output SPSS 16.0

Berdasarkan hasil pengujian yang ditunjukkan pada tabel nilai tolerance variabel bebas lebih dari $10 \%$ atau 0.1 dimana nilai tolerance dari Devidend Per Share (X1) sebesar 0.708 dan VIF sebesar 1.413, Earning Per Share (X2) sebesar 0.863 dan VIF sebesar 1.159 dan Net Profit Margin (X3) sebesar 0.665 dan VIF sebesar 1.504. Dengan demikian dapat disimpulkan bahwa tidak terjadi multikolinearitas karena nilai tolerance $>0.1$ dan $\mathrm{VIF}<10$.

\section{Uji Autokorelasi}

Untuk mendeteksi autokorelasi, dapat dlakukan uji statistik melalui uji DurbinWaston (DW test), ini mempunyai masalah mendasar yaitu tidak diketahuinya secara tepat mengenai distribusi dari statistik itu sendiri. Selanjutnya adalah membandingkan dengan tabel DW. Tabel DW terdiri atas dua nilai yaitu batas bawah (dl) dan batas atas (du). Berikut beberapa keputusan setelah membandingkan DW :

1. Bila DW terletak antara batas atas (du) dan (4-du), maka koefisien autokorelasi sama dengan nol, berarti tidak ada autokorelasi.

2. Bila DW lebih rendah dari pada atas bawah (dl), maka koefisien autokorelasi lebih besar daripada nol, berarti ada autokorelasi positif.

3. Bila nilai DW lebih besar daripada (4dl), maka koefisien autokorelasi lebih kecil daripada nol, berarti ada autokorelasi negative.

4. Bila nilai DW terletak antara (4-du) dan (4-dl), maka hasilnya tidak dapat disimpulkan.

Hasil uji Durbin-Waston (DW test) dalam penlitian ini adalah sebagai berikut: 
Tabel VI.5

Hasil Uji Autokorelasi

Model Summary ${ }^{b}$

\begin{tabular}{|l|r|r|r|r|r|}
\hline Model & $\mathrm{R}$ & $\begin{array}{c}\mathrm{R} \\
\text { Square }\end{array}$ & $\begin{array}{r}\text { Adjusted } \\
\text { R Square }\end{array}$ & $\begin{array}{c}\text { Std. Error } \\
\text { of the } \\
\text { Estimate }\end{array}$ & $\begin{array}{r}\text { Durbin- } \\
\text { Watson }\end{array}$ \\
\hline 1 &, $346^{\mathrm{a}}$ &, 120 &, 068 & 9,76671 & 1,561 \\
\hline
\end{tabular}

a. Predictors: (Constant), npm, eps, dps

b. Dependent Variable: harga saham

Sumber: Hasil olah data SPSS 16.0

\section{Analisis Regresi Berganda}

Analisis Regresi Berganda digunakan untuk mengetahui ada tidaknya pengaruh dari variable indepeden. Sehingga diperoleh olah data sebagai berikut:

Table VI.2

Hasil Uji Regresi Berganda

Coefficients $^{\text {a }}$

\begin{tabular}{|c|c|c|c|c|c|c|}
\hline \multirow[b]{2}{*}{ Model } & \multicolumn{4}{|c|}{\begin{tabular}{|l|l|} 
Unstandardized Coefficients Standardized Coefficients \\
\end{tabular}} & \multirow[b]{2}{*}{$t$} & \multirow[b]{2}{*}{ Sig. } \\
\hline & $\mathrm{B}$ & Std. Error & Beta & & & \\
\hline 1 (Constant) & 26,048 & 6,153 & & & 4,233 &, 000 \\
\hline Dps & ,526 & ,252 & & ,325 & 2,084 &, 042 \\
\hline Eps & ,042 & , 106 & &, 056 & ,396 & ,693 \\
\hline $\mathrm{Npm}$ &,- 871 & ,359 & &,- 391 & $-2,424$ &, 019 \\
\hline
\end{tabular}

a. Dependent Variable: harga saham

Sumber: Hasil olah data SPSS 16.0

Persamaan regresi didapat $\mathrm{Y}=26.048+$ $0.526(\mathrm{X} 1)+0.042(\mathrm{X} 2)+-0.871(\mathrm{X} 3)+\mathrm{e}$ sehingga dapat dibagikan penjelasan sebagai berikut:

Konstanta sebesar 26.048 artinya jika Devidend Per Share, Earning Per Share dan Net Profit Margin bernilai nol maka nilai harga saham nilainya 26.048 satuan.

Koefisien regresi variabel Devidend Per Share sebesar 0.526 artinya Devidend Per Share jika mengalami kenaikan satu kali,maka besarnya harga saham akan mengalami kenaikan sebesar 0.526 satuan.

Koefisien bernilai positif artinya terjadi hubungan positif antara Devidend Per Share dengan harga saham, semakin naik Devidend Per Share maka semakin meningkat harga saham

Koefsien regresi variabel Earning Per Share sebesar 0.042 artinya Earning Per Share jika mengalami kenaikan satu kali, maka besarnya harga saham akan mengalami

kenaikan sebesebesar 0.042 satuan. Koefisien bernilai positif artinya terjadinya hubungan positif antara Earning Per Share dengan harga saham, semakin naik Earning Per Share maka semakin meningkat harga saham.

Koefisien regresi variabel Net Profit Margin sebesar 0.359 artinya Net Profit Margin jika mengalami kenaikan satu kali, maka besarnya harga saham akan mengalami penurunan sebesar 0.359 satuan. Koefisien bernilai negative artinya terjadi hubungan negative antara Net Profit Margin dengan harga saham, semakin naik Net Profit Margin semakin menurun harga saham.

Uji Kelayakkan Model

Uji Koefisien Determinasi $\left(\mathrm{R}^{2}\right)$

Pengujian ini digunakan untuk mengetahui tingkat ketepatan yang terbaik dalam analisis regresi. Dalam hal ini ditunjukkan oleh besarnya koefisien determinasi. 
Table VI.6

Hasil Uji Koefisien Determinasi $\left(\mathbf{R}^{2}\right)$

Model Summary

\begin{tabular}{|c|r|r|r|r|}
\hline Model & $\mathrm{R}$ & $\mathrm{R}$ Square & Adjusted R Square & Std. Error of the Estimate \\
\hline 1 &, $346^{\mathrm{a}}$ &, 120 &, 068 & 9,76671 \\
\hline
\end{tabular}

a. Predictors: (Constant), npm, eps, dps

Besarnya sumbangan variabel Independen (X1, X2 dan X3) terhadap variable (Y) adalah $68 \%$ sedangkan sisanya $32 \%$ dipengaruhi oleh variabel lain. Hal ini dibuktikan dengan nilai $r$ square sebesar 0.083 (nilai koefisien determinasi atau $\mathrm{r}^{2}$ diperoleh dengan cara $0.068 \times 100 \%=68.0$ $\%$.
Uji F-Statistik

Uji F dilakukan untuk menilai pengaruh Devidend Per Share, Earning Per Share dan Net Profit Margin secara simultan terhadap harga saham. Berdasarkan hasil pengolahan data dengan program SPSS versi 16.0 maka diperoleh hasil sebagai berikut:

Tabel VI.7

Hasil Uji F

ANOVA

\begin{tabular}{|rl|r|r|r|r|r|}
\hline Model & & Sum of Squares & Df & Mean Square & F & Sig. \\
\hline 1 & Regression & 662,730 & 3 & 220,910 & 2,316 &, $087^{\circ}$ \\
& Residual & 4864,820 & 51 & 95,389 & & \\
& Total & 5527,550 & 54 & & & \\
\hline
\end{tabular}

a. Dependent Variable: harga saham

b. Predictors: (Constant), npm, eps, dps

Sumber: Hasil Output SPSS 16.0

Dari hasil uji simultan pada tabel VI.7 di atas dapat diketahui bahwa nilai $\mathrm{F}$ hitung sebesar 2.316 dengan nilai signifikansi sebesar 0.087. Berdasarkan hasil analisis tersebut dapat disimpulkan bahwa varibel indpenden tidak berpengaruh secara simultan terhadap variable dependen. Hal ini dikarenakan nilai signifikansinya $>0.05$ $(0.087>0.05)$.

\section{Pengujian Hipotesis}

Uji t

Analisis ini digunakan untuk mengetahui pengaruh secara individual variabel independen Deviden Per Share, Earning Per Share dan Net Profit Margin terhadap Harga Saham. Adapun hasil setelah data diolah sebagai berikut:

\section{Tabel VI.3}

Coefficients $^{\mathrm{a}}$

\begin{tabular}{|c|c|c|c|c|c|c|}
\hline \multirow{2}{*}{\multicolumn{2}{|c|}{ Model }} & \multicolumn{2}{|c|}{$\begin{array}{l}\text { Unstandardized } \\
\text { Coefficients }\end{array}$} & \multirow{2}{*}{$\begin{array}{c}\text { Standardized } \\
\text { Coefficients } \\
\text { Beta }\end{array}$} & \multirow[b]{2}{*}{$t$} & \multirow[b]{2}{*}{ Sig. } \\
\hline & & B & $\begin{array}{l}\text { Std. } \\
\text { Error }\end{array}$ & & & \\
\hline \multirow[t]{4}{*}{1} & (Constant) & 26,048 & 6,153 & & 4,233 & ,000 \\
\hline & Dps & ,526 & ,252 & ,325 & 2,084 &, 042 \\
\hline & Eps & , 042 & 106 & ,056 & ,396 & 693 \\
\hline & $\mathrm{Npm}$ &,- 871 & ,359 &,- 391 & 2,424 & 019, \\
\hline
\end{tabular}

a. Dependent Variable: harga saham

Sumber: Hasil Output SPSS 16.0

1.Pengujian Hipotesis Pertama

HI: Devidend Per Share memiliki pengaruh positif terhadap harga saham.

Berdasakan tabel diatas diperoleh variabel

Devidend Per Share sebesar sebesar nilai thitung $=2.084$ dengan probabilitas 0.042 nilai signifikan diatas 0.05 menunjukkan bahwa variabel dividend Per share memiliki pengaruh yang signifikan terhadap harga 
saham.dengan demikian $\mathrm{Hl}$ ditolak.

Menerima Ho dan menolak $\mathrm{Ha}$.

2.Pengujian Hipotesis Kedua

H2: Earning Per Share memiliki pengaruh positif terhadap harga saham.

Berdasarkan tabel diatas diperoleh hasil variabel Earning Per Share sebesar nilai thitung $=0.396$ dengan probabilitas sebesar 0.693. nilai signifikansi diatas 0,05 menunjukkan bahwa variabel Earning Per Share tidak memiliki pengaruh yang signifikan terhadap harga saham.dengan demikian $\mathrm{H} 2$ ditolak. Menerima Ho dan menolak Ha.

3.Pengujian Hipotesis Ketiga

H3: Net Profit Margin memiliki pengaruh negatif terhadap harga saham.

Berdasarkan tabel diatas diperoleh hasil variabel Net Profit Margin sebesar nila thitung $=-2.424$ dengan probabilitas sebesar 0,019. Nilai signifikansi dibawah 0,05 menunjukkan bahwa variabel Net Profit Margin memiliki pengaruh yang signifikan terhadap harga saham.dengan demikian $\mathrm{H3}$ diterima. Menerima Ha dan menolak Ho.

\section{PEMBAHASAN}

Berdasarkan hasil analisis Uji $\mathrm{F}$ secara simultan/bersama dapat disimpulkan bahwa varibel indpenden (harga saham) tidak berpengaruh secara simultan terhadap variable dependen (Deviden Per Share, Earning Per Share dan Net Profit Margin). Hal ini dikarenakan nilai signifikansinya $>0.05(0,087>0.05)$.

Berdasarkan koefisien determinasi Adjusted $R$ Square yang diperoleh $68 \%$ menjelaskan bahwa naik turunnya harga saham secara bersama-sama dipengaruh oleh ketiga variabel tersebut, yaitu Deviden Per Share, Earning Per Share dan Net Profit Margin, sedangkan sisanya $32 \%$ dipengaruhi oleh variabel lain yang tidak diteliti.

Devidend Per Share, Earning Per Share dan Net Profit Margin secara simultan/bersama-sama mempunyai tidak memiliki pengaruh yang signifikan terhadap Harga Saham Pada Perusahaan Persero yang
Terdaftar di BEI Periode 2013-2017.

Devidend Per Share sebagai X1 secara parsial berpengaruh signifikan terhadap harga saham Pada Perusahaan Persero yang Terdaftar di BEI Periode 2013, hal ini dibuktikan dengan adanya nilai $\mathrm{t}$ hitung 2.084 dapat disimpulkan bahwa berpengaruh karena nilai signifikasinnya $<0.05(0.042>0.05)$ sehingga $h_{a}$ diterima.

Erning Per Share sebagai X2 secara parsial tidak berpengaruh signifikan terhadap harga saham Pada Perusahaan Persero yang Terdaftar di BEI Periode 2013-2017, hal ini dibuktikan dengan adanya nilai $\mathrm{t}$ hitung 0.396 dapat disimpulkan bahwa tidak berpengaruh karena nilai signifikansinya $>0.05(0.693>0.05)$ sehingga $\mathrm{h}_{0}$ diterima

Net Profit Margin sebagai X3 secara parsial memiliki pengaruh positif namun tidak berpengaruh signifikan terhadap harga saham Pada Perusahaan Persero yang Terdaftar di BEI Periode 2013-2017, hal ini dibuktikan dengan adanya nilai $\mathrm{t}$ hitung 2.424 dapat disimpulkan bahwa tidak berpengaruh karena nilai signifikansinya $<0.05(0.019<0.05)$ sehingga $h_{a}$ diterima

\section{SIMPULAN}

Berdasarkan pembahasan yang telah dilakukan pada babsebelumnya, maka diperoleh kesimplan sebagai berikut:

1. Pada uji regresi serempak (bersama-sama), semua variabel bebas yang diteliti (DPS, EPS dan NPM) tidak memiliki pengaruh yang signifikan terhadap harga saham.

2. Pada uji regresi secara parsial atau masingmasing hanya variabel Devidend Per Share dan Net Profit Margin yang memiliki pengaruh signifikan terhdap harga saham, maka dapat dikatakan bahwa DPS dan NPM memiliki kontribusi dominan terhadap harga saham.

\section{SARAN}

Berdasarkan analisis yang telah dilakukan dan kesimpulan yang telah dikemukakan, adapun saran yang peneliti ajukan sebagai berikut: 
1. Bagi Perusahan-perusahaan Persero yang terdaftar di BEI agar lebih memperhatikan dan mengontrol faktor substansi fundamental dan selalu memperhitungkan peluang keuntungan yang dapat diperoleh dari variabel yang bukan penelitian.

2. Harga saham (closing price) merupakan variabel terikat untuk menilai kinerja Pada Perusahaan Persero yang Terdaftar di BEI Periode 2013-2017 pada penelitian ini.

3. Peneliti hanya menggunakan Perusahaan Persero yang Terdaftar di BEI Periode 2013-2017 dan diharapkan untuk penelitian selanjutnya agar bisa lebih mengembangkan penelitian ini dengan menilai rasio keuangan lainnya dan menambah perusahaan untuk dijadikan sampel dan memperpanjang periode yang diteliti.

\section{DAFTAR PUSTAKA}

Fahmi Irham. 2014. Pengantar Manajemen Keuangan Teori dan Soal Jawab. Bandung: Alfabeta.

Kasmir. 2013. Analisis Laporan Keuangan, Edisi Pertama. Jakarta:PT. RajaGrafindo Persada.

Sugiyono. 2012. Metode Penelitian Kuantitatif, Kualitatif dan Kombinasi (Mixed Methods). Bandung: Alfabeta.

Sudana I Made. 2011. Manajemen Keuangan Perusahaan Teori dan Praktik. Surabaya: Erlangga.

Kasmir. 2010. Pengantar Manajemen Keuangan. Edisi Kedua. Jakarta: Kencana.

Harjito dan Martono. 2012. Manajemen Keuangan. Edisi ke-2. Yogyakarta: Ekonis

Hutami Putri Rescyana. 2012. Pengaruh Dividen Per Share, Return On Equity, dan Net Profit Margin Terhadap Harga Saham Pada Perusahaan Industri Manufaktur
Yang Tercatat di BEI Tahun 20062010. Jurnal Universitas Negeri Yogyakarta, 1 (1).

Priatinah Denies, Prabandaru Adhe Kusuma. 2012. Pengaruh Return On Investment, Earning per Share dan Deviden Per Share Terhadap Harga Saham Perusahaan Pertambangan Yang Terdaftar Di Bursa Efek Indonesia periode 2008 s/d 2010. Jurnal Universitas Negeri Yogyakarta, 1 (1).

Pratama Aditya, Teguh Erawati. 2014. Pengaruh Current Ratio, Debt To Equity Ratio, Return On Equity, Net Profit Margin, Dan Earning Per Share Terhadap Harga Saham Studi Pada Perusahaan Manufaktur Yang Terdaftar Di BursaEfek Indonesia Periode 2008-2011. Jurnal Akuntansi, 2 (1): 1-10.

Henny Septiana Amalia. 2010. Analisis Pengaruh Earning Per Share, Return On Investment, dan Debt to Equity Ratio Terhadap Harga Saham Perusahaan Farmasi Di BEI. Jurnal Manajemen dan Akuntansi. Vol 11. Nomor 2. Hal.98-106.

Irwadi Maulan. 2014. Pengaruh Devidend Per Share dan Earning Per Share Terhadap Harga Saham Industri Manufaktur Di BEI. Jurnal Akuntansi Politeknik Sekaya. Vol 1. No 1.

Watung Rosdian Widiawati dan IlatVentje. (2016). Pengaruh Return On Asset, Net Profit Margin, dan Earning Per share Terhadap Harga Saham Perusahaan Perbankan Di BEI Periode 2011-2015. Jurnal EMBA. Vol 4. No 2.

AstutiWati Aris. (2014). Pengaruh Earning Per Share dan Devidend Per Share Terhadap Harga Saham Perusahaan Pertambangan Yang Terdaftar Di BEI Periode 2008-2013. Jurnal Universitas Komputer Indonesia. 